\author{
МЕХАНІЗМ ДИВЕРСИФІКАЦІЇ ФІНАНСОВИХ РИЗИКІВ \\ ТА ЙОГО ОЦІНКА
}

\title{
THE MECHANISM OF DIVERSIFICATION OF FINANCIAL RISKS AND THEIR ASSESSMENT
}

УДК 336.7:330.3

DOI: https://doi.org/10.32843/infrastruct56-20

\section{Дереза В.M.}

к.е.н., доцент,

доцент кафедри фрінансів

банківської справи та страхування

Дніпровський національний університет

імені Олеся Гончара

\section{Dereza Viacheslav}

Oles Honchar Dnipro National University

\begin{abstract}
у статті розглянуто підходи до мінімізації фрінансових утрат шляхом диверсифрікації фрінансових ризиків, запропоновано вдосконалити механізм диверсисрікації фрінансових ризиків. Визначення найбільш ефрективних для суб'єкта економіки варіантів диверсифрікації доцільно здійснювати шляхом порівняння витрат на впровадження можливих варіантів та отриманого від диверсифрікаціі зниження рівня ризику. Запропоновано здійснювати оцінку інших варіантів мінімізації втрат від фрінансових ризиків, які може застосувати суб'єкт і які можна згрупувати так: хеджування ризиків, лімітування та компенсування ризиків. На основі статистичних даних розраховано значення коесріцієнта варіації депозитних та кредитних ставок, а також курсу гривні до іноземних валют. Запропоновано методику оцінки фрінансових наслідків для суб'єкта економіки від упровадження диверсифрікації фрінансових ризиків через порівняння рівня ризику або рівня можливих фрінансових утрат до та після процесу диверсифрікації.

Ключові слова: фрінансовий ризик, диверсифрікація, механізм, фрінансові втрати, коефріцієнт варіації.
\end{abstract}

В статье рассмотрены подходы к минимизации ффинансовых потерь путем диверсифрикации фринансовых рисков, предложено усовершенствовать механизм диверсифиикации фринансовых рисков. Определение наиболее эфрфективных для субъекта экономики вариантов диверсификации челесообразно осуществлять путем сравнения затрат на внедрение возможных вариантов и полученного от диверсифрикации снижения уровня риска. Предложено осуществлять оценку других вариантов минимизации потерь от финансовых рисков, которые может применить субъект и которые можно сгруппировать следующим образом: хеджирование рисков, лимитирование и компенсация рисков. На основе статистических данных рассчитаны значения коэфрорициента вариации депозитных и кредитных ставок, а также курса гривны по отношению к иностранным валютам. Предложена методика оценки фринансовых последствий для субъекта экономики от внедрения диверсификации оринансовых рисков путем сравнения уровня возможных фринансовых потерь до и после процесса диверсификации.

Ключевые слова: фринансовый риск, диверсифрикация, механизм, финансовые потери, коэфффициент вариации.

The article discusses approaches to minimizing financial losses by diversifying financial risks, it is proposed to improve the mechanism for diversifying financial risks, which should consist of the following stages: 1) Formation by the financial and economic department of the subject (enterprise, bank, investment company, etc.) of the input data, depending on the type of activity, among which the most typical are: volumes and structure of credit resources, their price, borrowing terms, loan currency, volumes and structure of product exports and imports of goods, export and import currencies, duration of the production cycle, volumes and structure of securities portfolio, types of securities, profitability indicators, types and the level of expenses. 2) Determination of the types of financial risks faced by an economic entity, and its measurement for each type, as well as the level of losses suffered by an economic entity in previous periods, in order to assess the feasibility of diversifying financial risks. 3) Determination of the most effective diversification options for an economic entity by comparing the costs of implementing possible options and the resulting from diversification by reducing the level of risk. 4) Assessment of other options for minimizing losses from financial risks that the entity can apply and which can be grouped as follows: hedging risks, limiting and compensating risks. 5) Calculation of financial implications for an economic entity from the introduction of financial risk diversification To do this, it is necessary to compare the costs and the expected effect of diversification, that is, will the level of risk decrease, or what will be the maximum possible financial losses. Calculated on the basis of statistical data, the values of the coefficient of variation of deposit and lending rates, as well as the exchange rate of UAH to foreign currencies. A methodology for assessing the level of possible financial losses and the effectiveness of the process of diversifying financial risks is proposed. The introduction of a mechanism for diversifying financial risks will help reduce financial losses by economic entities, which in turn will improve the overall financial results of their activities.

Key words: financial risk, diversification, mechanism, financial losses, coefficient of variation.

Постановка проблеми. Одним зі засобів мінімізації фрінансових утрат в умовах нестабільного зовнішнього оточення $\epsilon$ процес диверсифрікація фрінансових ризиків. Більшість дослідників не конкретизує порядок вибору варіанту диверсифрікації, при цьому запропоновані схеми вибору варіантів диверсифрікації фрінансових ризиків мають низку недоліків, що викликає необхідність удосконалення механізму прийняття рішень про диверсиорікацію.

Аналіз останніх досліджень і публікацій. Сьогодні є багато праць, що присвячені організації системи ризик-менеджменту у різноманітних установах, які розглядають проблеми класифрікації, вимірювання та прогнозування ризиків, а також інструментам моніторингу, порівняння, контролю та інсоормаційного забезпечення управління ризиками. Серед вітчизняних науковців присвятили свої роботи проблемам ризик-менеджменту О.М. Ткаченко, О.О. Сосновська [1], Н.В. Корж [2], Н.В. Тарасевич та ін.

Із метою уникнення втрат під час вкладання коштів (інвестор) або їх залучення (позичальник) 
певним суб'єктом постає проблема розподілу наявних ресурсів так, щоб отримані доходи повністю або частково компенсували отримані збитки (у разі їх виникнення), що можна досягти через упровадження дієвого механізму диверсифрікації фрінансових ризиків.

Виклад основного матеріалу дослідження. Із метою мінімізації втрат від негативних коливань вартості фрінансових ресурсів та оцінювання результатів від диверсифікації нами запропоновано вдосконалити механізм диверсифікації фрінансових ризиків, який, на нашу думку, повинен складатися з таких етапів (рис. 1).

На першому етапі фрінансово-економічним відділом суб'єкта (підприємства, банку, інвестиційної компанії тощо) фрормуються вхідні дані залежно від виду діяльності, серед яких, на нашу думку, найтиповішими є: обсяги та структура кредитних ресурсів, їх ціна, строки запозичення, валюта кредиту, обсяги та структура експорту продукції та імпорту товарів, валюти експорту та імпорту, тривалість виробничого циклу, обсяги та структура портфеля цінних паперів, види цінних паперів, показники прибутковості діяльності, види та рівень витрат.

На другому етапі необхідно визначити, з якими видами фрінансових ризиків стикається суб'єкт економіки, а також виміряти рівень ризику за кожним видом, рівень збитків, що зазнав суб'єкт економіки у попередні періоди, з метою оцінювання доцільності диверсифікації фрінансових ризиків.

У науковій літературі існує значний перелік видів ризиків за різними ознаками, найчастіше до фрінансових ризиків відносять такі: валютний (зміна курсу валюти), процентний (зміна рівня ставок) та інвестиційний (зміна ціни активу). Цей перелік, звісно, можна розширити залежно від сорери та особливостей фрункціонування того чи іншого суб'єкта економіки.

Щодо вимірювання ризиків виділяють такі основні варіанти: фрундаментальні показники (дисперсія, середньоквадратичне відхилення, коефіцієнт варіації та ін.); шляхом порівняльної оцінки макроекономічних та фрінансових мультиплікаторів (курси валют, рівні ставок, рівень інфляції та ін.); через вимірювання ринкових показників привабливості сектору (за грошовими потоками, дивідендну доходність, технічними індикаторами галузі) та їхні коливання [2, с. 1-2].

На третьому етапі необхідно визначити найбільш еорективні для суб'єкта економіки варіанти диверсифікації. Для цього необхідно порівняти витрати на впровадження можливих варіантів з отриманим від диверсифрікації зниженням рівня ризику.

На четвертому етапі ми пропонуємо розглянути інші варіанти мінімізації втрат від орінансових ризиків, які може застосувати суб'єкт і які можна згрупувати так: хеджування ризиків, лімітування та компенсування ризиків [1, с. 74]. На цьому етапі доцільно передбачити економічні наслідки для різних варіантів, вибрати найбільш привабливий, а потім співставити з економічними наслідками процесу диверсифікації.

Кожен можливий варіант мінімізації втрат від фрінансових ризиків має відповідні організаційноекономічні особливості, пов'язані як із самим процесом, так і з можливостями самого суб'єкта

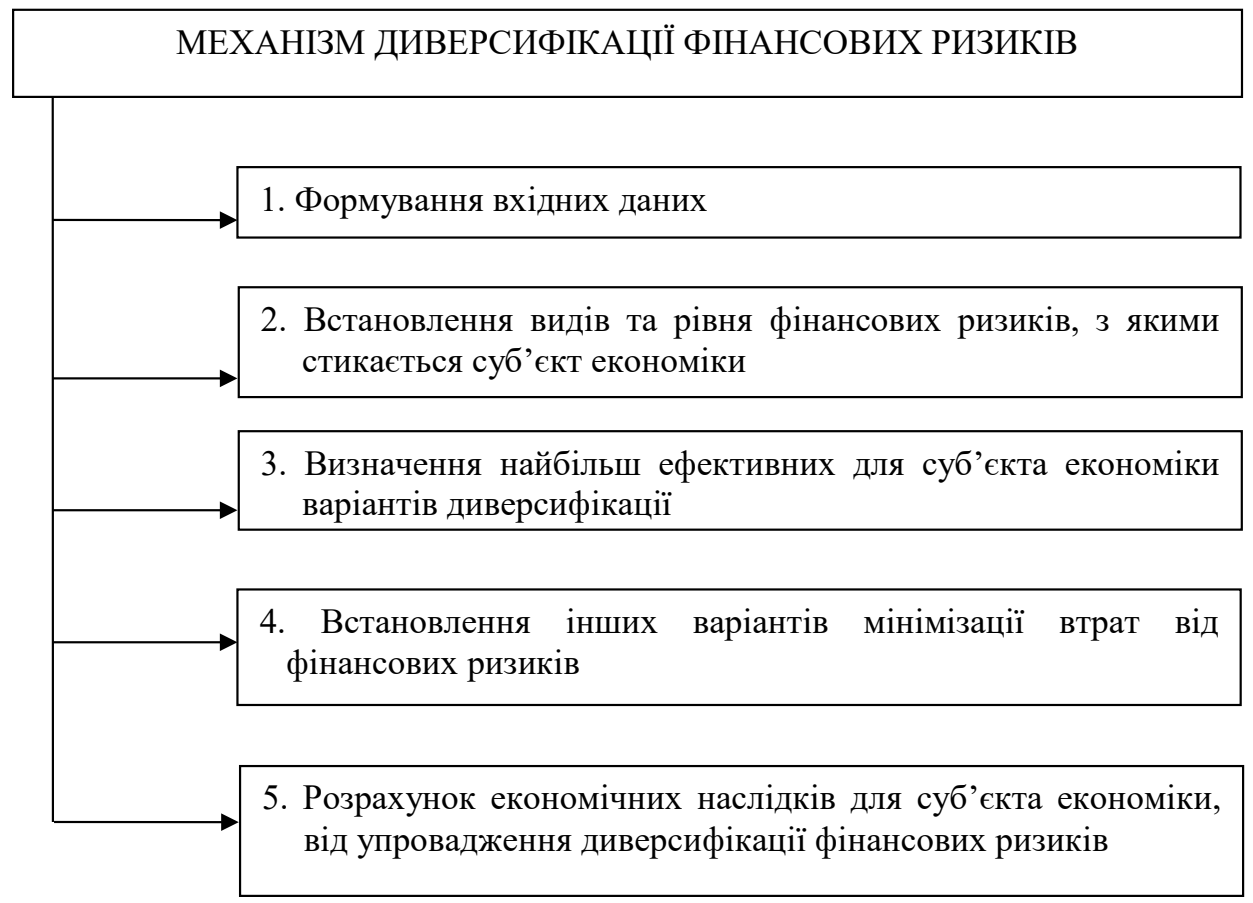

Рис. 1. Основні етапи механізму диверсифрікації фрінансових ризиків 
здійснювати ці заходи, наявністю потрібних спеціалістів, інститутів та інструментів або можливостей їх використання. Доцільність кожного варіанту слід визначати виходячи передусім із рівня можливих утрат, а також вірогідності їх настання. Так, використання деяких інструментів хеджування має економічний ефект, тобто стає доцільним, лише за значних розмірів діяльності. Певні інструменти в Україні взагалі не є доступними. Окрім того, є певна невизначеність майбутніх наслідків або процесів, що дає суб'єкту сподівання на сприятливий розвиток у подальшому і не мотивує до врахування можливих ризиків, не лише фрінансових. По-друге, у суб'єкта не завжди є можливість вилучити з обігу певні ресурси для передачі ризиків або на створення страхового фонду чи резервів для компенсації втрат, у цьому разі ризик отримання збитків ще більш зростає. Тому сам процес порівняння можливих засобів мінімізації фрінансових утрат повинен бути максимально обґрунтованим та прорахованим.

На п'ятому етапі здійснюється розрахунок фрінансових наслідків для суб'єкта економіки від упровадження диверсифікації фрінансових ризиків. Для цього необхідно порівняти витрати й очікуваний ефект від диверсифрікації, тобто чи знизиться рівень ризику або які при цьому будуть максимально можливі фрінансові втрати.

Як показник, за допомогою якого ми пропонуємо здійснювати оцінку можливих фрінансових утрат, рекомендуємо використовувати коефіцієнт варіації. Нами на основі статистичних даних НБУ за останні роки розраховано коефіцієнт варіації курсу валют та відсоткових ставок (табл. 1 та 2).

Дані таблиці засвідчують, що суб'єкт економіки, який отримав або надав короткостроковий кредит у національній валюті на один рік, має ризик зазнати збитків від коливання кредитної ставки у розмірі $20,1 \%$, що за умовної суми фрінансових витрат за кредитом, наприклад 1 млн грн, становитиме 201 тис грн, це означає, що позичальник має сплатити додаткові, не передбачені бюджетом кошти за користування позичкою. Так, наприклад, суб'єкт, який отримав позику, скажемо, під 7,7\%, що даними НБУ було зафріксовано 02.10.20, у момент іiї повернення 31.12.21, коли ставка дорівнювала
14,5\%, мав би заплатити вдвічі більшу суму відсотків, або, навпаки, кредитор отримав би вдвічі меншу суму. Звісно, це майже екстремальний випадок і в реальному житті не стався б, але для довгострокових кредитних відносин, де передбачено регулярний перегляд ставок, це досить вірогідно, про що свідчать розраховані значення коливання розміру довгострокових ставок у 2020 р. в Україні, які зафріксовано на рівні 14\%. Річне коливання рівня відсоткових ставок за довгостроковими депозитами в іноземній валюті для суб'єктів господарювання становить 82,6\%, що говорить про значний ризик зазнати втрат для суб'єкта, що розмістить або залучить такі ресурси, при цьому ставки у цей період змінювалися у межах від 0\% до $4,8 \%$ річних.

Так само це може відбуватися і з різноманітними валютними операціями. На валютному ринку відбувається щоденне коливання курсів валют. У табл. 2 представлено розрахунок коефріцієнту варіації курсу гривні до долара США та до євро валют, з яким здійснюється найбільше розрахунків у ЗЕД, аналогічно можна розрахувати варіацію курсу між будь-якими валютами, що використовує суб'єкт економіки.

Як свідчать розраховані значення, розмір можливих утрат від зміни курсу валют залежно від виду валют може становити у розрахунку на умовні 1 млн грн у середньому від 40 тис до 85 тис грн за одну валютну операцію на місяць, а якщо такі операції відбуваються частіше і на більшу суму, відповідно, зростають і можливі втрати.

Що стосується оцінювання можливих утрат від інвестиційних операцій, також уважаємо за доцільне визначати коефіцієнт варіації вартості відповідних активів за рік або на основі біржових торгів (для цінних паперів, що мають обіг на організованому ринку), або за розміром чистих активів чи показниками прибутковості (для емітентів, цінні папери яких не обертаються на ринку), хоча у цьому разі можливі маніпуляції з боку власників.

Під час здійснення диверсифрікації наявних ресурсів ми рекомендуємо спиратися на запропоновані раніше можливі варіанти диверсифікації, а саме: галузеву - розподіл між різними сорерами економіки, просторову - розподіл за місцем

Коефіцієнт варіації середньозваженої за день вартості у процентах річних у 2020 р. для суб'єктів господарювання

\begin{tabular}{|l|c|c|c|c|c|c|}
\hline \multirow{2}{*}{ Коефріцієнт варіації: } & \multicolumn{2}{|c|}{ національна валюта } & \multicolumn{3}{c|}{ іноземна валюта } \\
\cline { 2 - 7 } & усього & $\begin{array}{c}\text { коротко- } \\
\text { строкові }\end{array}$ & $\begin{array}{c}\text { довго- } \\
\text { строкові }\end{array}$ & усього & $\begin{array}{c}\text { коротко- } \\
\text { строкові }\end{array}$ & $\begin{array}{c}\text { довго- } \\
\text { строкові }\end{array}$ \\
\hline $\begin{array}{l}\text { - вартості кредитів за даними } \\
\text { статистичної звітності банків України, \% }\end{array}$ & 20,1 & 21,0 & 14,0 & 17,4 & 19,2 & 15,6 \\
\hline $\begin{array}{l}\text { - вартості строкових депозитів за даними } \\
\text { статистичної звітності банків України, \% }\end{array}$ & 33,8 & 34,3 & 23,2 & 40,3 & 42,2 & 82,6 \\
\hline
\end{tabular}

Джерело: ссрормовано автором на основі [4] 
Коефріцієнт варіації курсу гривні до іноземних валют на кінець місяця у 2020 р.

\begin{tabular}{|c|c|c|c|c|c|c|}
\hline Курс & 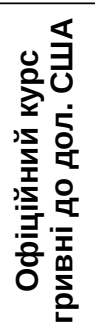 & 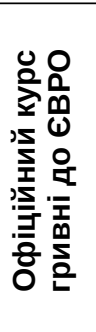 & 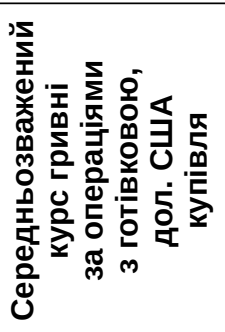 & 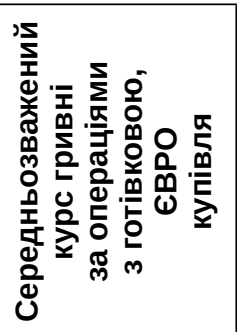 & 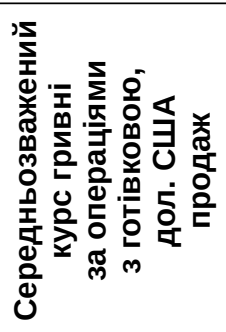 & 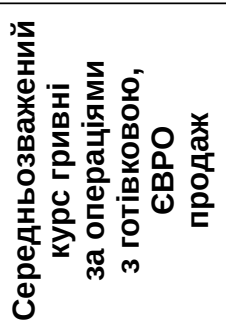 \\
\hline Коефріцієнт варіації \% & 4,84 & 8,22 & 5,09 & 8,34 & 5,18 & 8,56 \\
\hline
\end{tabular}

Джерело: сорормовано автором на основі [5]

(країною) походження, структурну - розподіл між різними видами активів (облігації, акції, валюта тощо) та комплексну - поєднання двох або трьох попередніх варіантів [3, с. 45].

Під час визначення можливих варіантів диверсифрікації слід розглядати інструменти або активи, які не мають між собою тісного взаємозв'язку, тобто кореляція ризику між якими рекомендується в межах $(-0,3 \geq \rho \leq 0,3)$.

Визначення питомої ваги кожного окремого активу у загальному обсязі ресурсів, що слід диверсифікувати, визначаться шляхом розв'язання задачі лінійного програмування в якій цільовою фуннцією виступає загальний рівень ризику. Відповідно, кращим буде такий набір активів, за якого загальний ризик буде мінімальним.

У сучасній практиці математичного програмування існує багато різноманітних методів програмування, за допомогою яких можна визначити оптимальну структуру як інвестиційного, кредитного або депозитного портфеля активів, так і портфреля цінних паперів.

Оцінку ефрективності диверсифрікації фрінансових ризиків ми пропонуємо здійснювати порівнянням розміру можливих фрінансових утрат до здійснення диверсифікації, тобто коли всі ресурси вкладені в один актив, 3 можливими втратами після диверсифікації, коли ресурси вкладені у кілька активів, за такою фрормулою:

$$
\frac{\mathrm{V}_{0}}{\mathrm{~V}_{1}}>1
$$

де $\mathrm{V}_{0}-$ можливі фрінансові втрати до диверсифрікації, грн;

$\mathrm{V}_{1}$ - можливі фрінансові втрати після диверсифрікації, грн.

Висновки 3 проведеного дослідження. За результатами проведеного дослідження запропоновано механізм диверсисрікації фрінансових ризиків шляхом вибору та порівняльної оцінки варіантів диверсифікації, а також інших методів мінімізації втрат від фрінансових ризиків, що дасть змогу суб'єкту економіки знизити ймовірність отримання збитків від фрінансово-кредитних та біржових операцій, а також оцінити ефективність цього механізму. Установлено, що від коливання процентних ставок на банківському ринку України суб'єкт економіки ризикує отримати орінансові (процентні) втрати у межах від 14\% до 82\% залежно від терміну позики та валюти кредиту. Аналіз коливання курсу гривні до долара США та євро в Україні встановив, що можна зазнати фрінансових утрат у межах 4,8-8,5\% залежно від виду конверсійних операцій. Під час визначення можливих варіантів диверсифрікації доцільно розглядати інструменти або активи, які не мають між собою тісного взаємозв'язку. Оцінювати ефективність диверсифрікації слід через порівняння розміру можливих фрінансових утрат до та після здійснення диверсифікації. Упровадження механізму диверсифрікації фрінансових ризиків сприятиме зниженню фрінансових утрат суб'єктами економіки, що, своєю чергою, дасть змогу поліпшити загальні фрінансові результати їхньої діяльності. Також подальшого розвитку потребує вдосконалення інших підходів до мінімізації фрінансових ризиків, зокрема розроблення методики компенсування можливих фрінансових утрат.

\section{БІБЛІОГРАФІЧНИЙ СПИСОК:}

1. Сосновська О.О., Деденко Л.В. Ризик-менеджмент як інструмент забезпечення стійкого функціонування підприємства в умовах невизначеності. Європейський науковий журнал економічних та фрінансових інновацій. 2019 . № 1(3). С. 70-76.

2. Корж Н.В. Методи управління фрінансовими ризиками. Траектория науки. 2016. Т. 2. № 10 С. 1.1-1.6.

3. Дереза В.М. Теоретичні аспекти диверсифікації фрінансових ризиків. Science and civilization - 2020 : materials of the XVI International scientific and practical conference, Sheffield. 30 January - 07 February 2020. Sheffield. 2020. C. 45-47.

4. Грошово-кредитна статистика. Національний банк України. URL: https://bank.gov.ua/ua/statistic/ sector-financial/data-sector-financial\#1ms (дата звернення: 15.06.2021).

5. Ооріційний курс гривні до іноземних валют (середній за період). Національний банк України. URL: https://bank.gov.ua/ua/markets/currency-market (дата звернення: 15.06.2021). 
REFERENCES:

1. Sosnovska O.O., Dedenko L.V. (2019) Ryzykmenedzhment yak instrument zabezpechennya stiykoho funktsionuvannya pidpryyemstva $v$ umovakh nevyznachenosti [Risk management as an instrument for providing the stable functioning of the enterprise in understanding conditions]. European scientific journal of Economic and Financial innovation (electronic journal), no. 1(3), pp. 70-76. Available at: https://journal.eae.com.ua (accessed 8 January 2021).

2. Korzh N.V. (2016) Metody upravlinnya finansovymy ryzykamy [Methods of financial risk management]. Traektoria nauki (electronic journal), vol. 2, no. 10, pp. 1.1-1.6. Available at: http://oaji.net/articles/2016/3992-1478384580.pdf (accessed 26 May 2021).
3. Dereza Viacheslav (2020) Teoretychni aspekty dyversyfikatsiyi finansovykh ryzykiv [Theoretical aspects of financial risk diversification]. Proceedings of the XVI International scientific and practical Conference Science and civilization - 2020. Economic science, (30 January - 07 February , 2020). Sheffield. Science and education LTD, vol. 7, pp. 45-47.

4. Groshovo-kreditna statistika [Monetary statistics]. URL: https://bank.gov.ua/ua/statistic/sectorfinancial/data-sector-financial\#1ms (accessed 15 June 2021).

5. Oficijnij kurs grivni do inozemnih valyut (serednij za period) [Official hryvnia exchange rate against foreign currencies (period average)]. URL: https://bank.gov.ua/ ua/markets/currency-market (accessed 15 June 2021). 